\title{
Erratum to: Changes in western disturbances over the Western Himalayas in a warming environment
}

\author{
R. K. Madhura $\cdot$ R. Krishnan $\cdot$ J. V. Revadekar • \\ M. Mujumdar $\cdot$ B. N. Goswami
}

Published online: 4 June 2014

(C) Springer-Verlag Berlin Heidelberg 2014

\section{Erratum to: Clim Dyn}

DOI 10.1007/s00382-014-2166-9

In the original publication of the article, there were errors in the Mathematical Expression for "C" on Page 9. The greek prefix "theta" was missing in the expression.

The correct Mathematical expression should read as given below:

$C=\frac{f^{2}\left(u_{200}-u_{700}\right) \theta_{500}}{\beta g H\left(\theta_{200}-\theta_{700}\right)}$

The online version of the original article can be found under doi:10.1007/s00382-014-2166-9.

R. K. Madhura · R. Krishnan $(\bowtie) \cdot$ J. V. Revadekar .

M. Mujumdar · B. N. Goswami

Center for Climate Change Research, Indian Institute of Tropical

Meteorology, Pune 411008, India

e-mail: krish@tropmet.res.in 